\title{
ヒトの視運動性眼振に対する視運動訓練効果と機構の検討
}

\author{
水田 啓介・久世 文也・青木 光広・中村 好克 \\ 海田 健宏 - 小塩, 勝博 - 早川 和喜 - 小川 晴子 \\ 宮崎 哲郎・浅野幸一郎・宮田 英雄
}

\section{Studies on Optokinetic Training}

Keisuke Mizuta, Bunya Kuze, Mitsuhiro Aoki, Yoshikatsu Nakamura Takehiro Kaida, Katsuhiro Ojio, Kazuki Hayakawa, Haruko Ogawa

Tetsuro Miyazaki, Kouichiro Asano, Hideo Miyata

Department of Otorhinolaryngology, Gifu University School of Medicine

We investigated the mechanism by which repetitive optic stimulation affects optokinetic responses. Eleven persons, physically healthy, took part in this study. The subjects were stimulated optokinetically to the right. The angular velocity of the Ohm type drum was $50 \mathrm{deg} / \mathrm{sec}$, and the duration of the stimulation was 30 seconds. This stimulation was successively applied 5 times a day over a period of 3 weeks. Optokinetic nystagmus $(\mathrm{OKN})$ was recorded with electronystagmography and analyzed with a computer. Before and during this trial, we did 2 tests every week. First, the drum was rotated with an angular acceleration of $2 \mathrm{deg} / \mathrm{sec}^{2}$, and optokinetic adaptation limit (OAL) was estimated. Next, the drum was rotated with an equal velocity of 40, 60 and $80 \mathrm{deg} / \mathrm{sec}$. The initial rapid rise (IR), the maximum steady state slow phase velocity (SS) and the time constant of optokinetic afternystagmus (TC) were calculated. These items were evaluated with stimulation towards the right only in 5 subjects and with stimulation towards both the right and the left in 6 subjects.

Optokinetic training produced the following results: OAL increased significantly on stimulation towards the right, but did not increase on stimulation towards the left. SS increased significantly at a velocity of 60 and $80 \mathrm{deg} / \mathrm{sec}$ in both directions. IR increased significantly on stimulation toards the right, and increased slightly on stimulation towards the left. TC decreased on stimulation towards the right. We conclude that the increase of the slow phase velocity of OKN was due mainly to the enhanced function of the pursuit system, but other factors also had a role in training effects.

Key words: optokinetic training, pursuit, optokinetic adaptation limit, optokinetic afternystagmus

\footnotetext{
岐皁大学医学部耳鼻咽喉科学教室
} 


\section{はじめに}

時田 ${ }^{1)}$ は “眼のよい” 運動選手の視運動性眼振 $(\mathrm{OKN})$ は, 視運動刺激に対する眼の適応の限界 の向上がみられるのを観察している。また, 視運 動訓練の効果について, Miyoshi et $\mathrm{al}^{2)}$ は視運動 性眼振の増加を, Pfaltz と Kato ${ }^{3)}$ は OKN 緩徐 相速度の增加を, 戸村4) は視運動性眼振の眼の適 応の限界の上昇を報告している。しかし，視運動 訓練による視運動性眼振の向上がぞのような機序 で抏こるのかは明らかではない。今回，視運動性 眼振を構成する 2 つの機構, すなわち追従機構と 速度蓄積機構の両機構への訓練の影響を検討した。

\section{被験者と方法}

\section{1 . 被験者}

被験者はめまい・平衡障害の既往がない健康成 人 11 名 (男 8 名, 女 3 名, 23 歳から35歳) である。 被験者全員に本試験の内容を説明し，同意を得た。

\section{2. 方法}

視運動訓練には内面に12本の線条が付してある 直径 $1.5 \mathrm{~m}$, 高さ $2 \mathrm{~m}$ の $\mathrm{Ohm}$ 型大円筒を用いた。 被験者を円筒の中央の椅子に座らせ, 頭部を固定

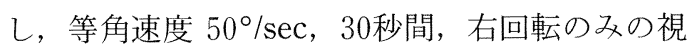
運動刺激を 1 日 5 回, 3 週間連日与えた。視運動 訓練時は被験者に線条を 1 本 1 本数えるように追 従するように指示した。

視運動性眼振は訓練前と訓練 1 週後, 2 週後, 3 週後に評価した。評価時の視運動刺激は 2 つの 方法を用いた。第 1 は訓練に用いた $\mathrm{Ohm}$ 型大円 筒を $2 \% / \mathrm{sec}^{2}$ の等角加速度で 60 秒間回転刺激し た。第 2 は同じ大円筒を $40^{\circ}, 60^{\circ}, 80^{\circ} / \mathrm{sec} の$ 等 角速度で 30 秒間回転刺激した。得られた眼振は電 気眼振計に記録するとともに，データ・レコーダ に記録し、コンピュータ（NEC PC9801）を用い て岐大眼振解析プログラムで分析し, 眼振緩徐相 速度を計算した。

11名の被験者のらち5名（被験者 No. 1 5) は上記した第 1 と第 2 の 2 つ視運動刺激で訓練 方向の右回転のみ，6名（被験者 No. 6 11）は 右・左の両回転について評価した。

3 . 検討事項

1) 視運動訓練効果についての検討

(1) 等角加速度刺激 $\left(2 \% / \mathrm{sec}^{2}\right)$ での視運動性眼 振の眼の適応の限界 (optokinetic adaptation limit, OAL)。円筒速度に比べて $3 \%$ sec までの追
従の遅れは正常範囲とし5)，追従し得た最大の円 筒速度とした。

(2)等角速度刺激 $\left(40^{\circ}, 60^{\circ}, 80^{\circ} / \mathrm{sec}\right)$ 時での最 高定常状態の眼振緩徐相速度 (steady-state of slow phase velocity, SS)。最高定常状態飞達し た始めの 5 打の平均を求めた。

2 ) 視運動性眼振向上の機構についての検討

(1)等角速度刺激時の OKN 第 1 打の緩徐相速度 (initial rapid rise, IR)。これは, OKN の追従機 構を検討するためである。

(2)等角速度刺激後の視運動性後眼振 (optokinetic afternystagmus, OKAN) の緩徐相速度の時定 数 (time constant, $\mathrm{TC}$ )。指数関数 $\mathrm{Y}=\mathrm{Ae}^{-\mathrm{t} / \tau} \mathrm{r}$ 近似させて求めた（ $て か ゙$ 時定数を表す）。これは, OKN の速度蓄積機構を検討するためである。

\section{結果}

1. 視運動訓練効果について

1) OAL について

代表例として被験者 1 の訓練前と訓練 3 週後の 等角加速度刺激 $\left(2 \% / \mathrm{sec}^{2}\right)$ 時の円筒速度と眼の 線条追従 (OKN 緩徐相速度) の関係を図 1 亿示 す。前述した方法で OAL を計算し, 訓練 3 週後 で OALの上昇が認められた。同椂にして求めた 全被験者の訓練による OAL の変化を図 2 に示 す。訓練と同方向 (右回転) では, 11名の OAL の平均値は訓練 3 週後では訓練前と比べて $\mathrm{t}$ 検定 で 1\%の危険率で有意差を認めた。しかし，訓練 と反対方向（左回転）では，6名（被験者 No. 6 〜11) の OAL の平均值は訓練前後で有意差を認 めなかった。これは, 両方向回転を評価した例と 1 方向回転のみ評価した例と個体差による影響も 考光られるため， 1 万向回転評価群 5 名（被験者 No. 1 5) と両方向回転評価群 6 名（被験者 No. 6〜11）を訓練に用いたのと同方向（右回転）の 訓練成績を検討した（図 3 )。訓練前に高い OAL を示した被験者 No. 4 と No. 6 を除いた 9 名で OALの上昇がみられ，両群ともに訓練前と比べ て訓練 3 週後の平均値の上昇は類似していた。

以上から，視運動訓練により OAL は訓練方向 と同側では上昇したが，反対側では上昇は示さな かった。

2) SS について

図 4 亿 $40^{\circ}, 60^{\circ}, 80^{\circ} / \mathrm{sec}$ の各等角円筒速度刺 激時での SS の訓練前後の平均値を示した。訓練 
訓練前

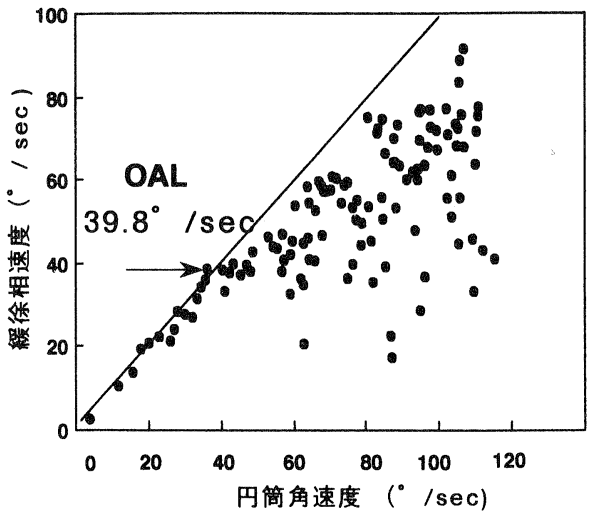

訓練後(3週後)

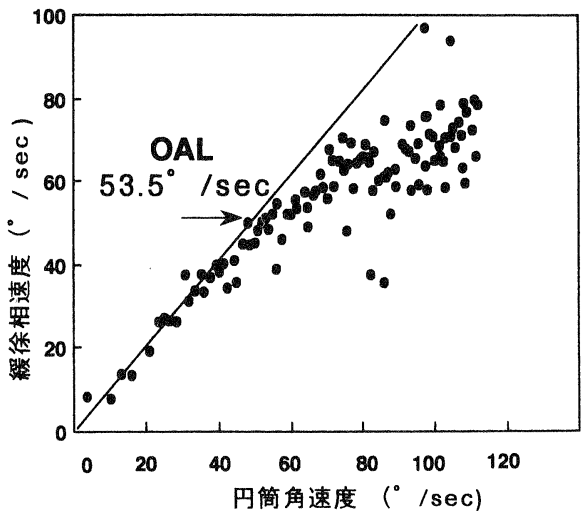

図1 等角加速度 $\left(2 \% / \mathrm{sec}^{2}\right)$ に上る訓練前後の OAL の変化（被験者 No. 1) 各プロットは円筒速度と線条追従（OKN 緩徐相速度）の関係を示している。実線は $\mathrm{y}=\mathrm{x}$ を示す。

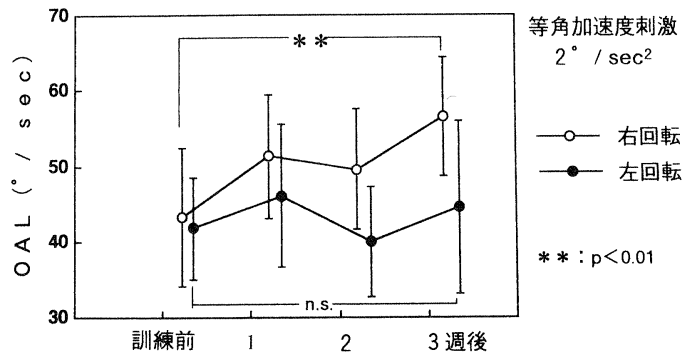

図 2 OAL の訓練による変化 $(1)$

等角加速度 $2 \% \mathrm{sec}^{2}$ 刺激での結果である。○は円筒右回転, は円筒左回転での成績を示し ている。訓練 3 週後で右回転は危険率 $1 \%$ で有意な上昇を認めるが，左回転では有意な差は 認めない。
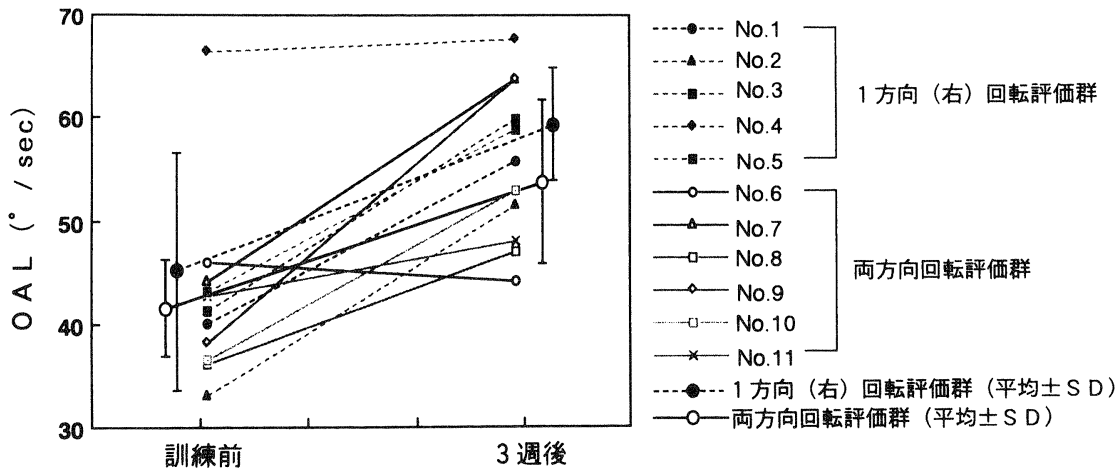

図 3 OAL の訓練による变化 $(2)-1$ 方向回転評価群と両方向回転評価群の成績一 1 方向のみ評価した群の平均（）と両方向を評価した群の平均 $(\bigcirc)$ の訓練前 後の変化は差は少なく類似している。 


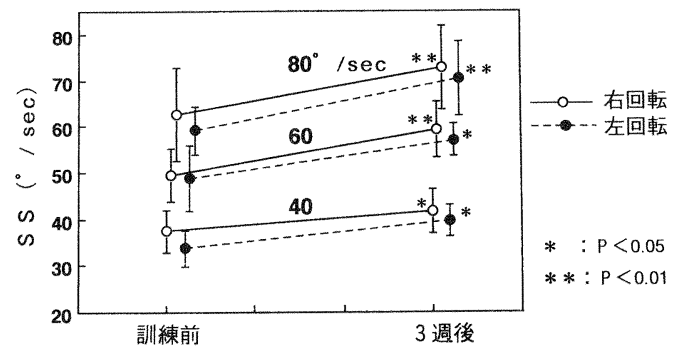

図 4 各刺激速度での訓練による SS の変化 $40 \% \mathrm{sec}, 60 \% \mathrm{sec}, 80 \% \mathrm{sec}$ の刺激速度で訓練前後で SS は有意差を認める。

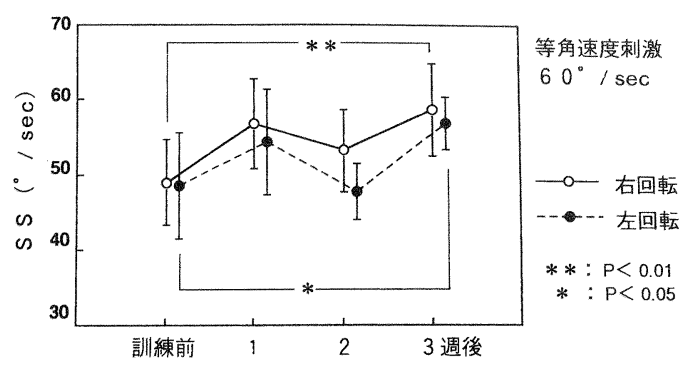

図 $5 \mathrm{SS}$ の訓練による変化（1） 刺激速度 $60 \% \mathrm{sec}$ での SS の变化を示す。右回転 (○), 左回転（）とも訓練 3 週後で有意な上昇 を認める。

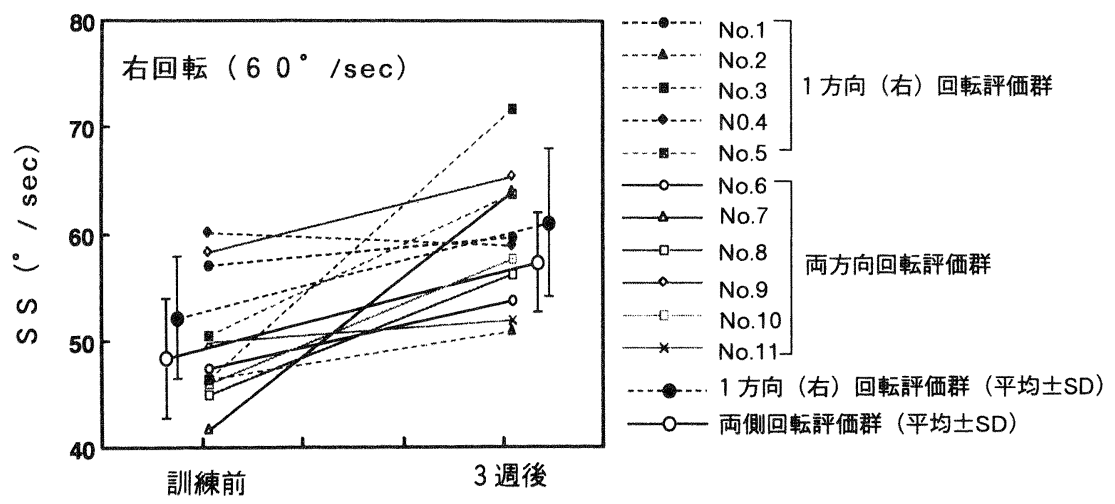

図 6 SS の訓練による变化 $(2)-1$ 方向回転評価群と両方向回転評価群の成績一 1 方向の又評価した群の平均 訓練前後の変化の差は少ない。

3 週後は訓練前と比べて訓練と同方向（右回転） では, 円筒速度 $40 \%$ sec は $\mathrm{t}$ 検定で危険率 $5 \%$ で, $60^{\circ}, 80^{\circ} / \mathrm{sec}$ は危険率 $1 \%$ で有意な差を認めた。 訓練と反対方向（左回転）では円筒速度 $40^{\circ}, 60$ \% $/ \mathrm{sec}$ は危険率 $5 \%$ で, $80 \%$ sec は危険率 $1 \%$ で有 意な差を認めた。

訓練による SS の訓練方向と同側叔よび反対側 刺激での变化について詳しく検討するため, 代表 として $60 \%$ sec での成績を示す。 $60 \%$ sec 刺激で の訓練による SS の変化を図 5 に示す。訓練と同 方向（右回転）は，11名の SS の平均值は訓練 3 週後は訓練前と比べて $\mathrm{t}$ 検定で $1 \%$ の危険率で有 意差を認め, 訓練と反対方向（左回転）は，6名 （被験者 No. 6 11）のSS の平均值は訓練 3 週後 は訓練前より $5 \%$ の危険率で有意差を認めた。次 に, OAL 之同様に 1 方向回転評価群 5 名之両方
向回転評価群 6 名の訓練と同方向（右回転）の訓 練成績を検討した（図 6 )。被験者 No. 4 以外の 10名で SS の上昇がみられ，両群ともに訓練前と 比べて訓練 3 週後の平均值の上昇は類似していた。

以上から, 視運動訓練により OKN の緩徐相速 度は訓練と同方向だけでなく反対方向に执いても 上昇がみられた。

2. 視運動性眼振向上の機構について

視運動訓練効果がどの機構の機能向上によるか を検討するために，SSを形成する 2 成分である 追従機構と速度蓄積機構を評価した。IR には追 従機構が関与するといわれ，TC は速度蓄積機構 を反映しているといわれている。この両者を検討 するためには OKAN が誘発されやすい条件で検 討する必要がある。今回の検討では, 等角速度 40 \% secの刺激では被験者によって OKAN が出現 


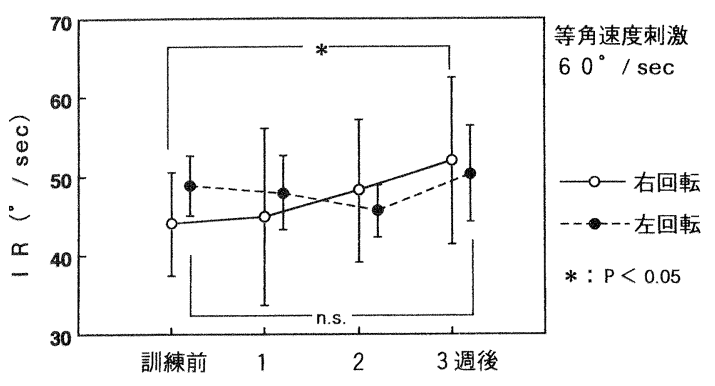

図 7 IR の訓練による変化 刺激速度 $60 \%$ sec での IR の変化を示す。右回転 $(O)$ では訓練 3 週後で有意差 (危険率 $5 \%$ ) を認めるが, 左回転（○）では有意な差は認めない。

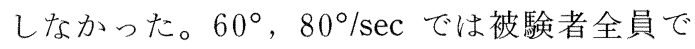
OKAN が誘発された。従って，代表として 60 \% /sec 刺激で検討した成績を示す。

1) IR について

$60 \%$ sec 刺激での IR の訓練による変化を図 7 に示す。訓練と同方向 (右回転) は, 11名の IR の平均值は訓練 3 週後では訓練前と比べて $\mathrm{t}$ 検定 で $5 \%$ の危険率で有意差を認めた。訓練と反対方 向（左回転）は，6名（被験者 No. 6 11）の IR の平均值は訓練前後で有意差を認めなかった。

以上から, 視運動訓練により, IR は訓練と同 方向では上昇し, 反対方向では上昇は汪とんどみ られなかった。

\section{2) TCについて}

$60 \%$ sec 刺激での TC の訓練による変化を図 8 に示す。訓練と同方向（右回転）および訓練と反 対方向 (左回転) ともに, TC の平均值は訓練 3 週後は訓練前と有意差を認めなかった。しかし， 同方向では TC が減少する傾向を認めた。

\section{考察}

1. 視運動訓練効果について

ヒトに护ける視運動性眼振に対する視運動訓練 効果については, Miyoshi et $\mathrm{al}^{2)}$ は $30 \%$ sec また は $60 \%$ sec の等角速度刺激を, 15秒間, 1 万向に 1 日 10 回, 10 日間与兄, 両方向の視運動眼振数之 緩徐相速度が増加したと, Pfaltz と Kato ${ }^{3)}$ は 30 $\% / \mathrm{sec}, 15$ 秒間の等角速度刺激を 1 万向に反復（1 日10回，10日間以上）与党て OKN 緩徐相速度の 増加と OKN の頻度の増加を認めたと報告してい る。戸村 ${ }^{4)}$ は $2 \% \mathrm{sec}^{2}, 90$ 秒間の等角加速度刺激 を 1 日に左右 2 回ずつ（計 4 回）, 3 週間与えて

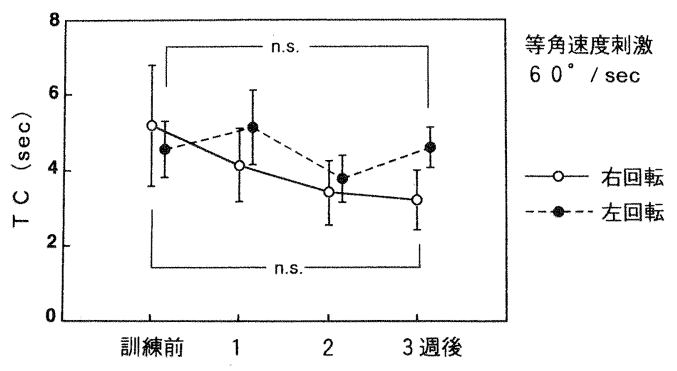

図 8 TC の訓練による変化

刺激速度 $60 \%$ sec での TC の変化を示す。右回転 （○）は訓練 3 週後で有意な差はないが，訓練によ り減少する傾向を認める。

OAL の上昇を報告している。

今回の成績では $50 \% \mathrm{sec}, 30$ 秒間，1 万向のみ 1 日 5 回, 3 週間の訓練で, Miyoshi et $\mathrm{al}^{2)}$ や Plaltz と Kato ${ }^{3)}$ が報告したよらに OKN 緩徐相速 度の増加と戸村）が示した OAL の上昇を認め た。しかし，どのような訓練条件（加速度刺激か 等速度刺激か, 刺激速度, 1 回当たりの訓練時間, 1 日の訓練回数, 訓練期間など）が最も訓練効果 が高いかは今後の課題である。

2. 視運動性眼振向上の機構について

OKN 緩徐相速度は fast component component から構成されていると考光られてい る11)。fast component は OKN 緩徐相速度の初期 急速増加成分を反映し，追従機構が関与している と考えられている。一方, slow component は緩 徐増加成分や OKAN 緩徐相速度を反映し, 速度 蓄積機構が関与していると考えられている。視運 動訓練による効果がこれらのどの機構に影響を与 光ているかについての報告はない。今回, 我々は この点を検討するために, fast component は OKN 緩徐相速度の初期急速増加（IR）により， slow component は OKAN の時定数（TC）で検 討した。

IR は訓練と同方向の視運動刺激で増加を認め た。すなわち，視運動訓練により訓練方向への追 従機能が向上したと考兄られた。OAL が訓練と 同方向刺激で上昇がみられたこともこの効果と考 えることができる。しかし，OKN 緩徐相速度は 訓練方向に増加がより大きかったが，反詨方向刺 激にも増加はみとめられた。従って, 訓練方向と 反対方向の追従機能をもある程度向上させること 
が考兄られた。また，視運動訓練による訓練方向 への追従機能の向上以外の効果が関与していると 考えられる。

Takemori6) や Cohen et $\mathrm{al}^{7)}$ は猿を用いて視運 動刺激を反復し与兄ることにより，OKANの TC が減少すると述べている。我々の成績でも OKAN の TC は訓練方向で短縮をみとめた。 OKAN の TC は速度蓄積機構を反映しているが， 訓練により OKAN の TC が短縮したことが， OKN 緩徐相速度を構成する slow component 成 分の減少を示すと考劣ると訓練する OKN 緩徐相 速度の増加を解釈することは難しい。このことか ら, OKAN の TC の短縮は Takemori6) いるように habituation としての効果と解釈した い。また，訓練方向と反対方向で認められた $\mathrm{OKN}$ 緩徐相速度増加の理由はまだ明確ではない が，速度蓄積機構への影響や視運動刺激に対して 注意力が高まるなどの alertnessへの影響を明ら かる必要があると思われる。

\section{まとめ}

ヒトの視運動性眼振に対する視運動訓練効果と その機構を検討した。

1. 健康成人 11 名衹運動訓練（等角速度 50 $\% / \mathrm{sec}, 30$ 秒間の刺激を 1 方向のみ 1 日 5 回, 連 日 3 週間）を施行した。OAL は訓練と同方向の 刺激では有意に上昇したが，反対方向では有意な 上昇はみられなかった。SS は両方向で有意増 加した。

2．IR は訓練方向のみで有意な増加を認めた。 TC は訓練と同方向刺激で減少する傾向を認め た。このことから，視運動訓練による訓練方向の 視運動性眼振の向上は追従機能が向上したためと
考光られた。訓練と反対方向での SS の増加の理 由はまだ明確でない。

本論文の要旨は第95回日本耳鼻咽喉科学会総 会，第75回，第76回東海地方部会連合講演会にて 口演した。

\section{文献}

1 ）時田 喬 : 眼振の生理と検査. 金原出版, 東 京, 1973

2) Miyoshi T, Pfaltz CR, Piffko P: Effect of repetitive stimulation upon optokinetic and vestibular responses. Acta Otolaryngol 75: 259-265, 1973

3 ) Pfaltz CR, Kato I: Vestibular habituation. Arch Otolaryngol 100: 444-448, 1974

4 ) 戸村義則：視運動脊䯣反射の検討.耳鼻臨床 77: 196-218, 1984

5 ) 菱田 登：小脳障害例の視運動性眼振. 耳鼻 臨床 47: 910-926, 1954

6 ) Takemori S: The similarities of optokinetic afternystagmus to the vestibular nystagmus. Ann Otol 83: 230-238, 1974

7 ) Cohen B, Matsuo V, Raphan T: Quantitative analysis of the velocity characteristics of optokinetic nystagmus and optokinetic afternystagmus. J Physiol 270: 321-344, 1977

8 ) Robinson DA: Models. Neurosci Res Prog Bull 18: 575-617, 1980

$\left(\begin{array}{l}\text { 原稿到着: 平成 } 6 \text { 年 } 6 \text { 月 } 29 \text { 日 } \\ \text { 別刷請求先 : 水田啓介 } \\ \text { 干500 岐阜市司町40 } \\ \text { 岐阜大学医学部耳鼻咽喉科学教室 }\end{array}\right)$

